\title{
A mutant receptor with enhanced dominant-negative activity for the blockade of human prolactin signalling
}

\author{
A Flynn*, H Whittington*, V Goffin ${ }^{1}$, J Uney and M Norman \\ Henry Wellcome Laboratories for Integrative Neuroscience and Endocrinology, University of Bristol, UK \\ ${ }^{1}$ INSERM Unit 584, Paris, France \\ (Requests for offprints should be addressed to M Norman; Email: m.r.norman@bris.ac.uk) \\ *(A Flynn and $\mathrm{H}$ Whittington contributed equally to this work)
}

\begin{abstract}
An effective mechanism for interfering with prolactin signalling would provide a powerful tool for clarifying the importance of prolactin in breast cancer, as well as for investigating functions of prolactin in other tissues. Based on our previous identification of a dominant-negative mutation in the growth hormone receptor that causes familial short stature, we investigated the potential for using a similar truncated mutant of the prolactin receptor (PRLR1-242). Like the mutant growth hormone receptor, PRLR1-242 exerts an exceptionally powerful dominant-negative effect. A probable explanation for the strong dominant-negative activity of this class of mutation is that, lacking internalisation motifs, the truncated mutants accumulate at the cell surface and form non-functional heterodimers with wild-type receptors. In accordance with evidence for heterodimer formation between the two receptors, PRLR1-242 also blocks signalling by the growth hormone receptor. When expressed from an adenoviral vector, PRLR1-242 inhibits activation of STAT5 (signal transducer and activator of transcription 5) by prolactin in T47-D breast cancer cells, and blocks the ability of prolactin to induce proliferation in these cells. Thus PRLR1-242 provides an effective means of blocking the responsiveness of target tissues to human prolactin.
\end{abstract}

Journal of Molecular Endocrinology (2004) 32, 385-396

\section{Introduction}

Recent studies have prompted a revival of interest in the possibility that prolactin might play an important role in human breast cancer (Vonderhaar 1999, Goffin et al. 1999, Clevenger et al. 2003). Early studies clearly showed the importance of prolactin in mammary cancer of rodents (Welsch \& Nagasawa 1977), but clinical trials of dopaminergic drugs in the human disease were disappointing (Manni et al. 1989) and interest in prolactin subsequently waned. Several factors have led to a reappraisal. In particular, it now appears that interference with the release of pituitary prolactin may be ineffective because prolactin is synthesised locally in breast tissue and is capable of acting in an autocrine manner (Glevenger et al. 1995, Ginsburg \& Vonderhaar 1995). Consequently, considerable effort has been expended in a search for prolactin antagonists capable of blocking the action of locally produced hormone (Fuh \& Wells 1995, Goffin et al. 1996, Chen et al. 1998). Although more work is required to maximise its effectiveness in vivo, the most recent prolactin antagonist shows considerable promise for effective blockade of prolactin action (Bernichtein et al. 2003). There is still, however, an urgent need for a technique that would allow tissue-specific ablation of prolactin responsiveness in target tissues. Such an approach would provide an opportunity to clarify the importance of prolactin in human breast cancer, as well as in other tissues such as prostate where prolactin might also have a role in tumorigenesis (Kindblom et al. 2003).

The prolactin receptor is a member of the cytokine receptor superfamily. As with other members of this family, intracellular signalling is initiated when binding of a ligand leads to activation of a Janus kinase (JAK). The prolactin 


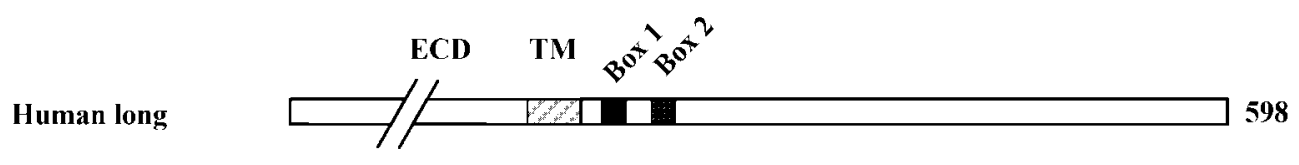

Human intermediate $\square / 725$

Human short (S1a) $\quad 376$

Human short (S1b)

Human PRI.R1-242

Rat short

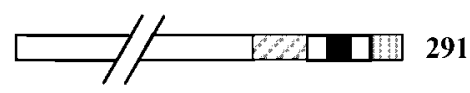

Figure 1 Comparison of mutant human prolactin receptor (PRLR1-242) with naturally occurring isoforms of the human and rat receptor. ECD, extracellular domain; TM, transmembrane.

receptor signals predominantly through the JAK2 kinase, which binds to a proline-rich sequence (box 1) located proximal to the transmembrane domain of the receptor (Bole-Feysot et al. 1998). Tyrosine phosphorylation of the receptor then leads to recruitment and activation of STAT5 (signal transducer and activator of transcription 5) which, together with mitogen-activated protein kinase (MAPK) and other signalling pathways, elicits a cellular response. Receptors with truncated cytoplasmic domains have proved particularly useful for mapping domains involved in activation of these signalling pathways (Bole-Feysot et al. 1998). Several 'short' forms that could function as modulators of the prolactin response occur naturally (Fig. 1). These truncated variants exert a dominant-negative effect on signalling via STAT5 (Perrot-Applanat et al. 1997, Hu et al. 2001, Trott et al. 2003), but they retain the box 1 sequence necessary for JAK2 binding. The ability of this sequence to signal via other pathways is emphasised by a recent study demonstrating its ability to rescue mammopoiesis in heterozygous mice (PRLR+/ - ) with only one copy of the prolactin receptor (Binart et al. 2003). Short forms retaining box 1 are therefore unsuitable for studies requiring complete blockade of prolactin action.
While investigating familial short stature resulting from resistance to growth hormone, we identified a dominant-negative mutation in the growth hormone receptor (Ayling et al. 1997). This mutation results in truncation of the receptor, so that the cytoplasmic domain consists of only seven amino acids and lacks motifs such as box 1 that are required for signalling. The dominant-negative action of the mutant is probably exerted by the formation of heterodimers (Ayling et al. 1997, Ross et al. 1997), and its unusually powerful effect can be explained by the loss of internalisation motifs resulting in accumulation of mutant receptor at the cell surface (Ayling et al. 1997, Maamra et al. 1999). Because of the close similarity between the growth hormone and prolactin receptors, we hypothesised that a similar mutation in the prolactin receptor would provide an equally potent means of blocking prolactin signalling. Here, we describe the characterisation of a truncated mutant of the prolactin receptor (PRLR1-242) which, unlike the naturally occurring short forms, lacks box 1. PRLR1-242 exerts a powerful dominant-negative effect over the wild-type receptor. When expressed by an adenoviral vector, this mutant completely blocks the mitogenic effect of prolactin on cultured human breast cancer cells. 


\section{Materials and methods}

\section{Recombinant human prolactin}

Recombinant human prolactin (rhPRL) was produced as described previously (Paris et al. 1990), but with an additional purification step: rhPRL was loaded on a monoQ HR 10/10 (8 ml) anion exchange column in $20 \mathrm{mM}$ Tris- $\mathrm{HCl}, \mathrm{pH} 8$ and eluted with a $\mathrm{NaCl}$ gradient. Oxidised human PRL elutes at around $100 \mathrm{mM} \mathrm{NaCl}$, while reduced rhPRL (i.e. incorrectly folded protein due to lack of disulphide bridge formation) elutes at slightly higher $\mathrm{NaCl}$ concentrations. The concentration of all prolactin solutions was checked by protein assay, and biological activity confirmed by the $\mathrm{Nb} 2$ bioassay (Tanaka et al. 1980).

\section{Plasmids}

A $2.7 \mathrm{~kb}$ EcoRI fragment containing the human prolactin receptor cDNA sequence preceded by the rat signal sequence (Lochnan et al. 1995) was subcloned from a pcDNA3 vector into the EcoRI site of the pAdlox plasmid to produce PRLRwt. The pAdlox plasmid is a shuttle vector incorporating loxP and adenoviral packaging sites required for adenovirus construction by the Cre-lox recombination method (see below). This plasmid also includes a cytomegalovirus (GMV) promoter allowing it to be used as a eukaryotic expression vector. Truncated receptor (PRLR1-242) was then constructed by PCR, introducing a stop codon after amino acid 242. The primers used were 5'GCAATGCATGCATG

CGATCTGCACTTGC-3' and 5'-GCATCGGT CGACTCAGCAGGTCACGATGGTATAGG-3' (primer 1). The PCR product was digested with SphI and SalI before being cloned into pAdlox digested with SphI and SalI. The $5^{\prime}$ untranslated region was then added by substituting the HindIII/BstEII in this construct by the HindIII/ BstEII fragment from PRLRwt. Plasmid encoding PRLR1-242 with a FLAG-tag at the amino terminus was constructed by PCR amplification of two fragments. The first fragment was produced using a primer which anneals to a site $5^{\prime}$ to the multiple cloning site of pAdlox (5'-CGATTGA CGCAAATGGGC-3', primer 4) and a primer which anneals to the $3^{\prime}$ end of the rat signal sequence attached to the FLAG sequence (5'CGTCATGGTCTTTGTAGTCGTGTCGCTTC
AGGAGGC-3'). The second fragment was produced using a primer which includes the FLAG sequence together with sequence coding for the amino terminus of the mature human prolactin receptor (5'-CAGGACTACAAAGACGATGACG ATAAATTACGTCGTGGAAAACGTG-3') and primer 1 . The resulting fragments were annealed and extended using primers 1 and 4 . The final PCR fragment was digested with SalI and ligated into the SalI site of pAdlox. Plasmid encoding wild-type receptor with an amino-terminal FLAG sequence was then constructed by SalI-BstEII digestion of FLAG-tagged PRLR1-242 and replacing the corresponding 5 ' sequence of PRLRwt. The lactogenic hormone response element reporter (LHRE-luc), which incorporates six tandem copies of the STAT5 response element derived from the $\beta$-casein promoter, and the pcDNA3 vector containing the human cDNA sequence encoding full-length prolactin receptor have been described previously (Goffin et al. 1996).

\section{Cell culture and transfection}

HEK 293 and T47-D cells were maintained in Dulbecco's modified Eagle's medium (DMEM; Life Technologies) supplemented with 10\% fetal bovine serum. Cells were transfected with Fugene 6 (Roche), and for all experiments a ratio of $3 \mu \mathrm{l}$ Fugene per microgram DNA was used. Total amounts of DNA for each well were balanced by adding pcDNA3 (Invitrogen). To correct for transfection efficiency, cells were cotransfected with $50 \mathrm{ng}$ pSV- $\beta$-galactosidase control vector (Promega) and luciferase activity was normalised to $\beta$-galactosidase activity. Assays using LHRE-luc reporter (Goffin et al. 1996) were performed in HEK 293 cells seeded in to 48-well plates $\left(2-3 \times 10^{4}\right.$ cells per well). Cells were transfected with the appropriate plasmids, incubated overnight, washed and transferred to serum-free medium (DMEM-F12 supplemented with $100 \mu \mathrm{g} /$ $\mathrm{ml}$ transferrin and $200 \mu \mathrm{g} / \mathrm{ml}$ BSA). Hormones were added $6-8 \mathrm{~h}$ later to a final concentration of $250 \mathrm{ng} / \mathrm{ml}$ unless otherwise stated. Luciferase activity was assayed 18-20 h later using a Dynex Microtiter plate luminometer. All measurements were performed in triplicate and in at least three separate experiments. Representative experiments are shown (means \pm S.E.M.). 


\section{Immunoprecipitation and Western blotting}

Cells were washed with cold PBS and scraped into

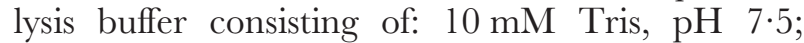
$5 \mathrm{mM}$ EDTA; $150 \mathrm{mM} \mathrm{NaCl} ; 30 \mathrm{mM}$ sodium pyrophosphate; $50 \mathrm{mM}$ NaF; $1 \mathrm{mM}$ sodium orthovanadate; $10 \%$ glycerol; $0 \cdot 5 \%$ Triton X-100; $1 \mathrm{mM}$ PMSF; and $5 \mu \mathrm{g} / \mathrm{ml}$ each of pepstatin, leupeptin and aprotinin. The extracts were incubated on ice for $20 \mathrm{~min}$ with occasional vortexing before centrifugation $(13000 \boldsymbol{g}$ for $10 \mathrm{~min}$ at $4{ }^{\circ} \mathrm{C}$ ). Clarified supernatants were mixed at $4{ }^{\circ} \mathrm{C}$ with $2 \mu \mathrm{g}$ anti-FLAG M2 monoclonal antibody for $2 \mathrm{~h}$, and then for a further $2 \mathrm{~h}$ with protein A-agarose. The precipitated agarose complexes were washed with lysis buffer $(2 \times 1 \mathrm{ml})$ and proteins were recovered by denaturing at $95{ }^{\circ} \mathrm{C}$ for 5 min in $2 \times$ concentrated sample buffer $(60 \mathrm{mM}$ Tris-HCl, pH 6.8; 10\% glycerol; 2\% SDS; trace of bromophenol blue). Equal volumes of sample were loaded onto 8\% SDS-polyacrylamide gels and electrophoresed overnight. Proteins were transferred to a PVDF membrane (Millipore) using a semi-dry Transblot (Bio-Rad) apparatus and the blots probed with anti-FLAG antibody followed by horseradish peroxidase (HRP)linked sheep anti-mouse antibody (Amersham). Blots were developed using the Enhanced Chemiluminescence system (Amersham).

For detection of activated STAT5, a biotinylated oligonucleotide (5'-AGATTTGTAGGAATTCAA ATC- $\left.3^{\prime}\right)$, derived from the $\beta$-casein promoter and including a STAT5 response element, was linked to streptavidin-agarose beads as described by Beadling et al. (1996) after annealing to an antisense strand. Before extraction of cellular proteins, beads were washed and resuspended as a slurry of approximately $50 \% \mathrm{v} / \mathrm{v}$ beads and buffer. Nuclear extracts were mixed with $10 \mu \mathrm{l}$ beads in $1 \mathrm{ml}$ lysis buffer and incubated at $4{ }^{\circ} \mathrm{C}$ for $2 \mathrm{~h}$ on a rotator. Analysis of bound proteins was then performed by Western blotting, as described above, using rabbit polyclonal anti-STAT5B (Santa Cruz, Santa Cruz, CA, USA). All experiments were performed at least three times and representative experiments are shown. Quantitation of Western blots was performed using Quantity 1 software (BioRad).

\section{Immunofluorescence microscopy}

Cells were washed with PBS containing 1\% charcoal stripped serum (PBSA), then incubated for $1 \mathrm{~h}$ on ice with $10 \mu \mathrm{g} / \mathrm{ml}$ anti-FLAG M2fluoroscein isothiocyanate (FITC) antibody (Sigma). After washing with cold PBSA, fluorescence was examined using a Leica DMRIB fluorescent microscope and image capture system (JVG).

\section{Use of iodinated anti-FLAG antibody to monitor receptor expression}

The M2 anti-FLAG antibody (Sigma) was iodinated using IODO-GEN tubes (Pierce Rockford, IL, USA) according to the manufacturer's instructions. Cells were seeded into 24-well plates at a density of 100000 cells per well and transfected the following day with $250 \mathrm{ng}$ /well of plasmid expressing FLAGtagged wild-type PRLR or PRLR1-242. After incubation, cells were washed twice with Dulbecco's PBS and fixed for $20 \mathrm{~min}$ in 4\% paraformaldehyde (PFA)/PBS then stored at $4{ }^{\circ} \mathrm{C}$. For binding assays, cells were incubated for $1 \mathrm{~h}$ at room temperature in PBSA containing $\left[{ }^{125} \mathrm{I}\right]$-labelled anti-FLAG (specific activity approximately $320 \mathrm{mCi} / \mathrm{mmol}$ ), then washed with PBS and lysed overnight in $1 \%$ SDS/ $0.2 \mathrm{M} \mathrm{NaOH}$. Radioactivity was adjusted for non-specific binding (antibody binding to cells transfected with plasmids expressing corresponding untagged receptors).

\section{Construction of adenoviral vector}

Recombinant viruses were constructed by cotransfection of CRE8 cells with pAdlox plasmids (PRLRwt.FLAG or PRLR1-242.FLAG) and $\psi 5$ DNA, as described previously (Hardy et al. 1997), to yield the $\psi$ PRLR1-242.FLAG adenovirus. The $\psi 5$ adenovirus is replication deficient and has deletions in the viral E1 and E3 regions. The packaging site is directly flanked by loxP sites so that it is deleted by recombination when the virus is cultured in CRE8 cells, a derivative of 293 cells containing the Cre recombinase gene. Thus there is negative selection for growth of the $\psi 5$ virus, and growth is restored by recombination with the loxP site in pAdlox. Recombinant virus was passaged twice in CRE8 cells to reduce contamination with $\psi 5$ adenovirus, and cell lysates were prepared by two rounds of freeze-thawing. Recombinant adenoviral particles were purified on $\mathrm{CsCl}$ gradients. Viral titres, which were approximately $10^{10}$ per ml, were determined by plaque assay. As a control, adenovirus lacking a transgene (Ad0) was used. 
$\mathbf{a}$

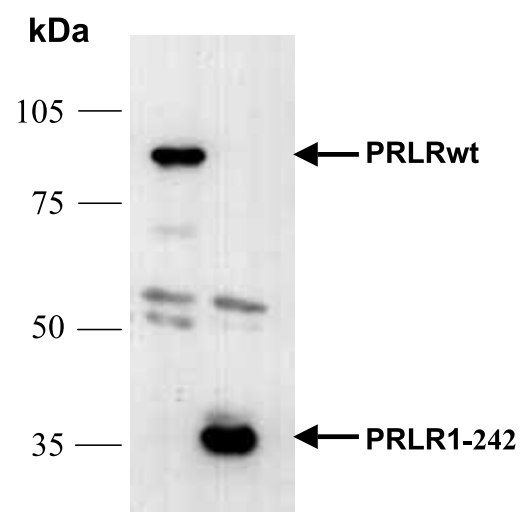

b

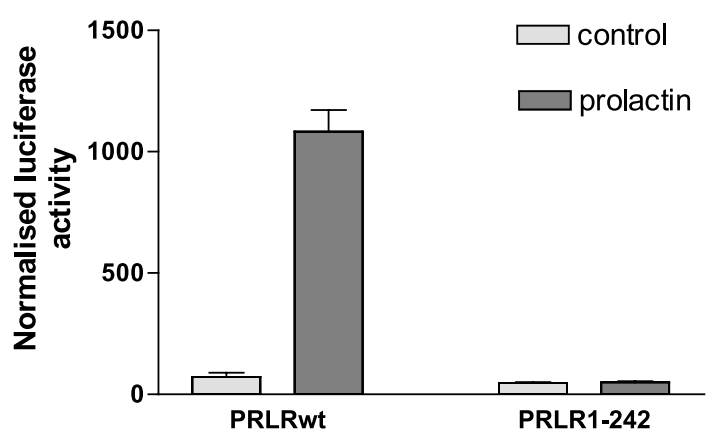

Figure 2 Expression of wild-type and mutant prolactin receptor in HEK 293 cells. (a) Western blot of proteins expressed by FLAG-tagged PRLRwt and PRLR1-242 plasmids. Proteins were immunoprecipitated and detected by anti-FLAG antibody M2. (b) Activation of the LHRE reporter by PRLRwt and PRLR1-242 in HEK 293 cells treated with vehicle or rhPRL $(250 \mathrm{ng} / \mathrm{ml})$. Error bars represent S.E.M. $(n=3)$

\section{Thymidine incorporation}

To measure $\left[{ }^{3} \mathrm{H}\right]$ thymidine incorporation, T47-D cells $\left(5 \times 10^{4}\right.$ per well $)$ were seeded into 96-well plates in medium containing $1 \%$ charcoal-stripped serum. After $24 \mathrm{~h}$, virus was added and cells were incubated for a further $24 \mathrm{~h}$ before addition of rhPRL $(500 \mathrm{ng} / \mathrm{ml})$ for the final $18 \mathrm{~h}$. One hour before harvesting, $\left[{ }^{3} \mathrm{H}\right]$ thymidine $(0 \cdot 1 \mu \mathrm{Ci} /$ well $)$ was added. Finally, cells were trypsinised and transferred to Printed Filtermats (Wallac, PerkinElmer, Beaconsfield, UK) for determination of radioactivity.

\section{Results}

\section{Expression and dominant-negative activity of the PRLR1-242 mutant}

HEK 293 cells transfected with plasmids coding for FLAG-tagged wild-type (PRLRwt) and mutant (PRLR1-242) prolactin receptor express proteins of the appropriate size (approximately 95 and $35 \mathrm{kDa}$ respectively) that are detectable by Western blotting using anti-FLAG antibody (Fig. 2a). We consistently found that the truncated mutant was expressed at markedly higher levels than the full-length receptor. When 293 cells were cotransfected with these plasmids together with the LHRE-luc reporter to detect activation of STAT5, prolactin caused a 15-fold increase in luciferase activity with the wild-type receptor. As expected, there was no increase with the mutant PRLR1-242 receptor that lacks box 1 (Fig. 2b). To test the ability of the PRLR1-242 mutant to inhibit signalling by the wild-type receptor, HEK 293 cells were cotransfected with equal amounts of PRLRwt and PRLR1-242 plasmid together with the LHRE-luc reporter. As shown in Fig. 3a, $24 \mathrm{~h}$ after transfection the mutant receptor has a potent inhibitory effect on the ability of wildtype prolactin receptor to activate STAT5. The growth hormone receptor, which is closely related to the prolactin receptor, is also expressed in breast cancer cells and may contribute to progression of the disease (Mertani et al. 1998, Gebre-Medhin et al. 2001). Given the close similarity between growth hormone and prolactin receptors, together with evidence for formation of heterodimers between these two receptors (Herman et al. 2000) and the ability of human growth hormone to bind both receptors (Cunningham et al. 1990), we predicted that PRLR1-242 would also inhibit signalling by the growth hormone receptor. As shown in Fig. 3b, this is indeed the case: signalling by the human growth hormone receptor is strongly inhibited by PRLR1-242.

When cells were transfected with equal amounts of plasmid expressing wild-type and mutant receptor, we consistently found that signalling was inhibited by considerably more than might be expected if inhibition were due simply to formation of inactive heterodimers. The potency of this mutant is further emphasised by results obtained 

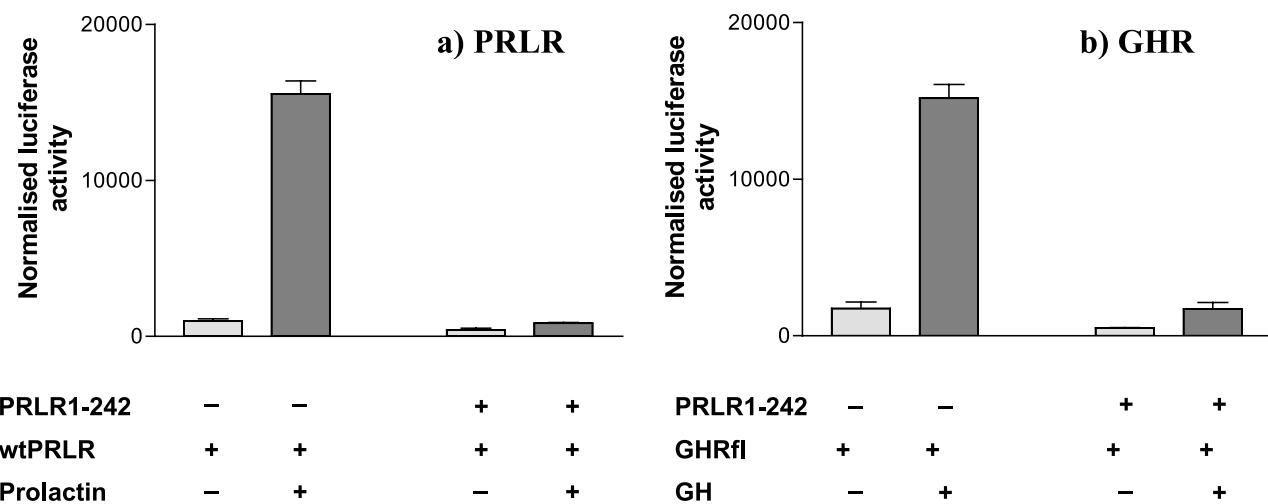

\begin{tabular}{|c|c|c|c|c|c|c|c|c|c|}
\hline PRLR1-242 & - & - & + & + & PRLR1-242 & - & - & + & + \\
\hline wtPRLR & + & + & + & + & GHRfI & + & + & + & + \\
\hline Prolactin & - & + & - & + & GH & - & + & - & + \\
\hline
\end{tabular}

Figure 3 Effect of cotransfecting mutant prolactin receptor together with wild-type human prolactin or growth hormone receptor in HEK 293 cells. (a) PRLRwt (100 ng) plus PRLR1-242 (100 ng) were cotransfected into HEK 293 cells together with the LHRE reporter (100 $\mathrm{ng})$, and cells treated with vehicle or $\mathrm{rhPRL}(250 \mathrm{ng} / \mathrm{ml})$. (b) Wild-type human growth hormone receptor (GHRfl; $100 \mathrm{ng})$ plus PRLR1-242 (100 ng) were cotransfected into HEK 293 cells together with the LHRE reporter (100 ng), and cells treated with vehicle or recombinant human growth hormone $(250 \mathrm{ng} / \mathrm{ml})$. Error bars represent S.E.M. $(n=3)$.

when different ratios of wild-type and mutant receptor are cotransfected (Fig. 4). Strong inhibition is achieved when plasmid expressing mutant receptor is cotransfected at only one-fifth the concentration of plasmid encoding wild-type receptor. Inhibition is almost maximal when cells are transfected with equal amounts of wild-type and mutant receptor, with only a small additional inhibition being observed when a fivefold excess of mutant plasmid is used (results not shown). Thus the slight variation in degree of inhibition found in different experiments (compare Figs $3 \mathrm{a}$ and 4) probably reflects differences in the rate at which PRLR1-242 accumulates (see later). These results

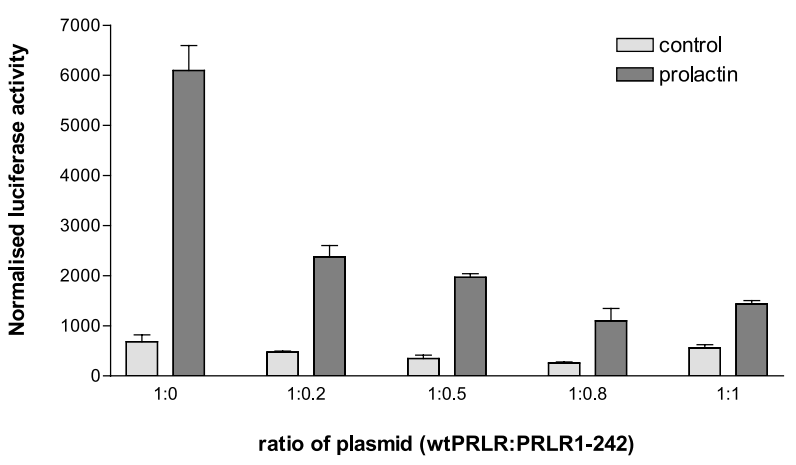

Figure 4 Effect of cotransfecting different ratios of wild-type and mutant prolactin receptor in HEK 293 cells. PRLRwt (100 ng) and PRLR1-242 (0-100 ng) were cotransfected into HEK 293 cells together with the LHRE reporter (100 ng) and treated with vehicle or rhPRL $(250 \mathrm{ng} / \mathrm{ml})$. Error bars represent S.E.M. $(n=3)$. are reminiscent of the powerful dominant-negative effect that we observed with the dominantnegative growth hormone receptor mutation (Ayling et al. 1997).

\section{The enhanced dominant-negative activity of PRLR1-242 is likely to result from preferential accumulation of the mutant}

Because the PRLR1-242 mutant lacks internalisation motifs, we predicted that expression of the mutant relative to wild-type receptor would increase with time. To test this prediction, expression of FLAG-tagged receptors was determined by measuring binding of iodinated antiFLAG antibody to the cell surface at different times after transfection of cells (Fig. 5a). As predicted, expression of wild-type receptor was found to decline after about $48 \mathrm{~h}$, while the mutant receptor either reached a plateau or continued to increase, so that there is a significant $(P<0.05)$ increase in the ratio of mutant to wild-type receptor with time (Fig. 5b). A consequence of this effect should be that the dominant-negative effect of PRLR1-242 would increase correspondingly. To test this prediction, HEK 293 cells were cotransfected with PRLR1-242 and a fivefold excess of wildtype PRLR, together with LHRE-luc reporter. Induction of luciferase activity by exposing the cells to prolactin for $6 \mathrm{~h}$ at different times after transfection was then measured. Although 

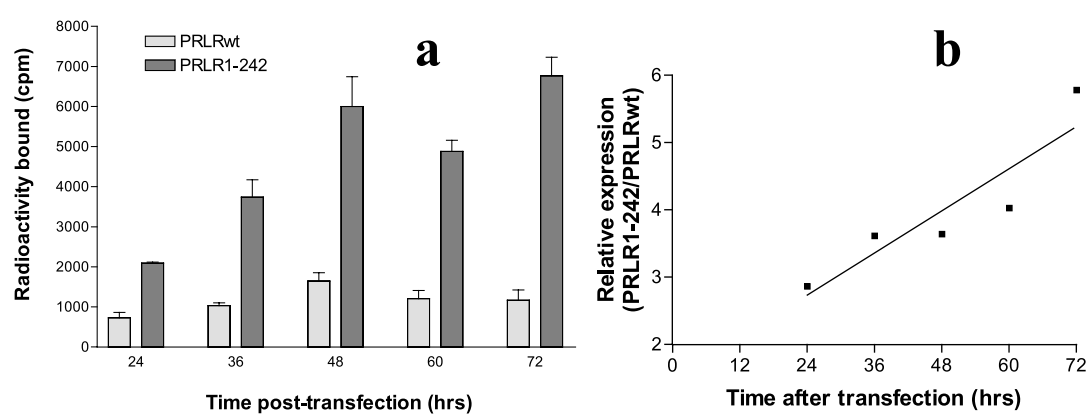

Figure 5 Expression of wild-type and mutant prolactin receptor at different times after transfection. (a) Cells were fixed at various times after transfection with FLAG-tagged PRLRwt or PRLR1-242, and binding of ${ }^{125}$ I-labelled anti-FLAG antibody measured. Error bars represent S.E.M. $(n=3)$. (b) Relative expression of wtPRLR and PRLR1-242 expressed as a ratio of bound radioactivity.

activation of luciferase from wild-type receptor declines with time (Fig. 6a), presumably reflecting decay of plasmids encoding receptor and/or reporter genes, there is a significant $(P<0.05)$ increase in efficacy of the dominant-negative mutant with time (Fig. 6b). Both of these experiments confirm our prediction that, relative to wild-type, mutant receptors accumulate at the cell surface with time.

\section{Expression of PRLR1-242 from an adenoviral vector blocks the proliferative response of breast cancer cells to prolactin}

To test the ability of PRLR1-242 to block cellular responses to prolactin, we took advantage of the T47-D human breast cancer cell line which expresses high levels of prolactin receptors, and proliferates in response to prolactin. The low
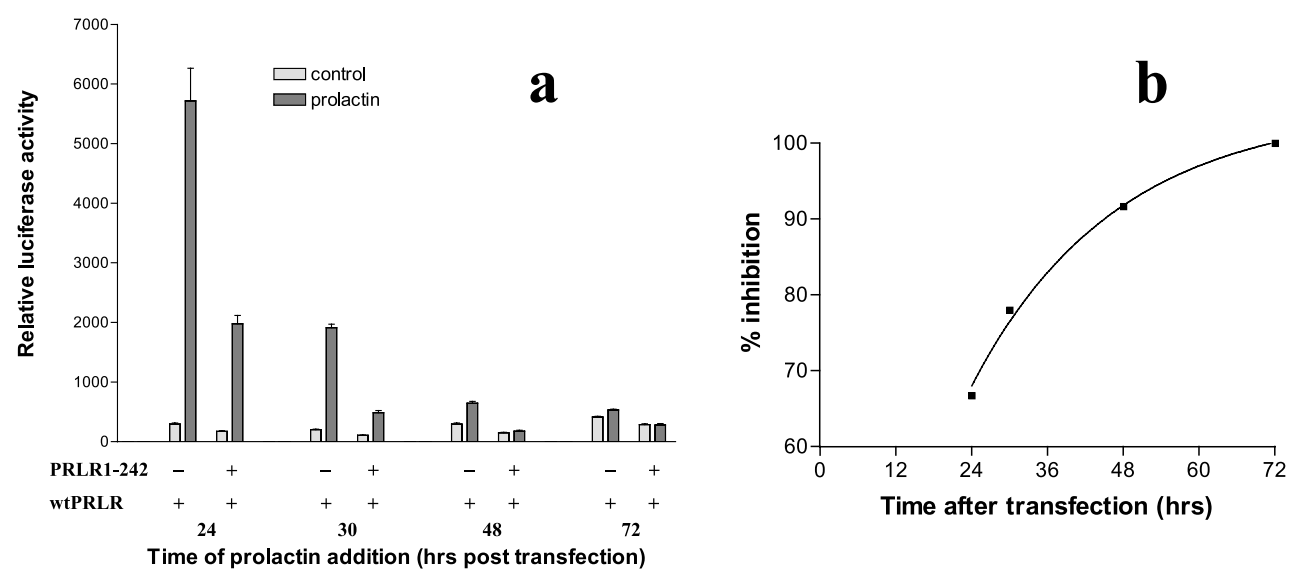

Figure 6 Potency of the dominant-negative activity of mutant prolactin receptor at different times after transfection. (a) Luciferase activity was measured at different times after transfection of HEK 293 cells in 12-well plates (100 000 cells/well) with PRLRwt (400 ng) and PRLR1-242 (100 ng) together with the LHRE reporter (400 ng). After transfection, cells were cultured in DMEM for various times before being transferred to serum-free medium for $18 \mathrm{~h}$. rhPRL $(250 \mathrm{ng} / \mathrm{ml})$ was then added for a further $6 \mathrm{~h}$ before harvesting of cells. (b) Percentage inhibition of signalling by PRLR1-242 calculated as:

(wt- mut)/wt $\times 100$, where wt=luciferase activity with PRLRwt alone and mut=luciferase activity with PRLRwt plus PRLR1-242 (both corrected for luciferase activity in the absence of hormone). 


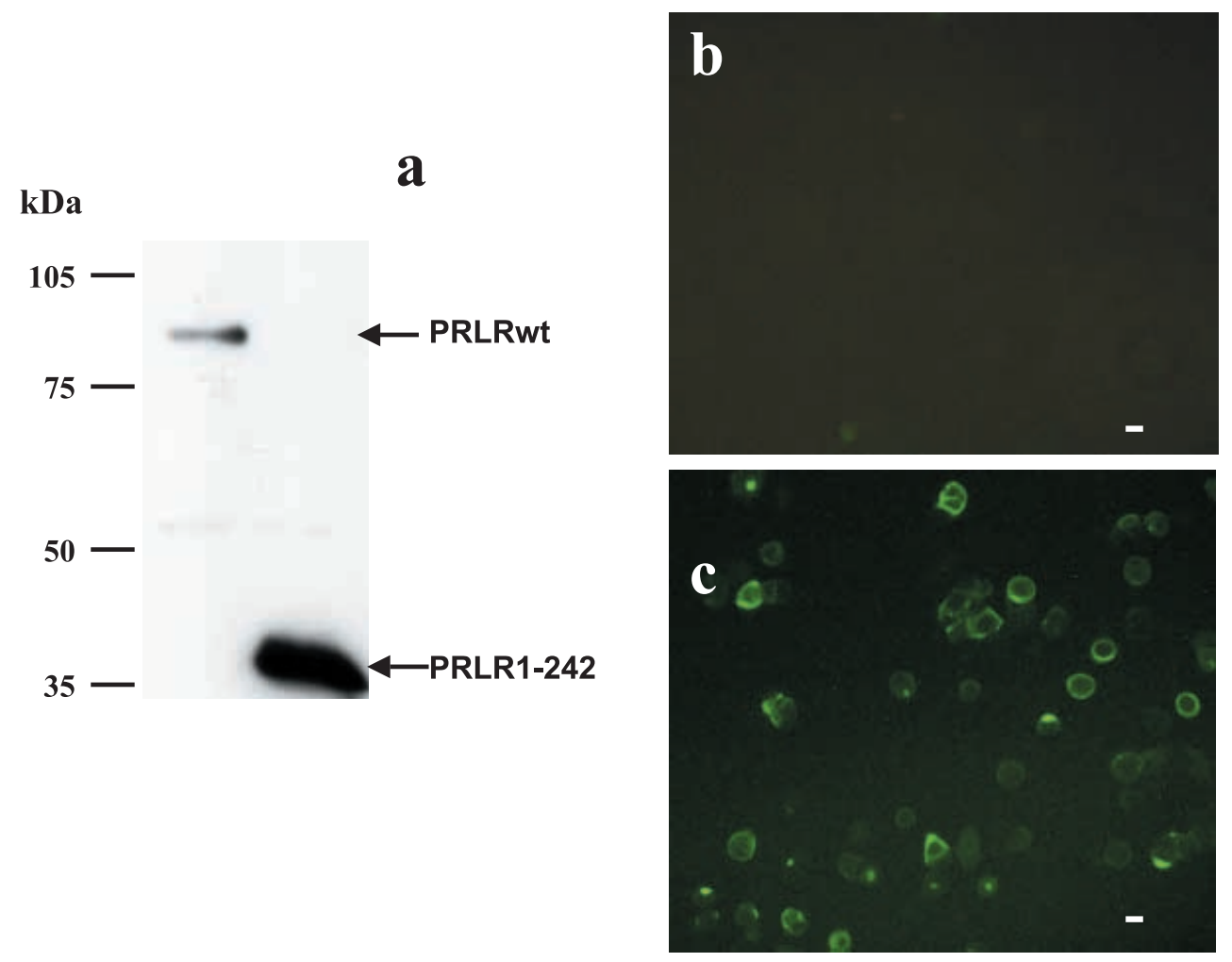

Figure 7 Adenoviral-mediated expression of wild-type and mutant prolactin receptor in T47-D cells transduced with adenoviral vectors. (a) Western blot using anti-FLAG antibody (adenoviral infection at MOI 100). (b) and (c) Fluorescence using FITC-labelled anti-FLAG and cells infected with adenoviral vector expressing PRLRwt and PRLR1-242 respectively (MOI 50). Scale bar, $10 \mu \mathrm{m}$.

transfection efficiency we obtained with these cells (about 5-10\%) precluded studies involving transfection with plasmids, but infection with adenoviral constructs encoding wild-type receptor and the PRLR1-242 mutant resulted in efficient expression of proteins of the appropriate size (Fig. 7a), which could also be detected immunohistochemically on the surface of T47-D cells infected with a viral multiplicity of infection (MOI) of 50 (Fig. 7b). At this MOI, fluorescence was detectable in about $70 \%$ of cells infected with virus encoding PRLR1-242. As before, both assays demonstrated markedly higher expression of the mutant protein, the wild-type receptor being barely detectable by immunohistochemistry at an MOI of 50.

Next, we tested the ability of PRLR1-242 to inhibit activation of STAT5 by prolactin in T47-D cells. Using a DNA response element to bind activated STAT5 (Beadling et al. 1996), no detectable STAT5 is extracted from untreated cells, but treatment with prolactin for $20 \mathrm{~min}$ induces a marked increase in STAT5 able to bind the response element. Some diminution of the ability of prolactin to activate STAT5 was apparent when cells were infected with Ad0 at an MOI of 50 or $100(2 \cdot 9$ and $20 \cdot 1 \%$ respectively, see Fig. 8$)$. With

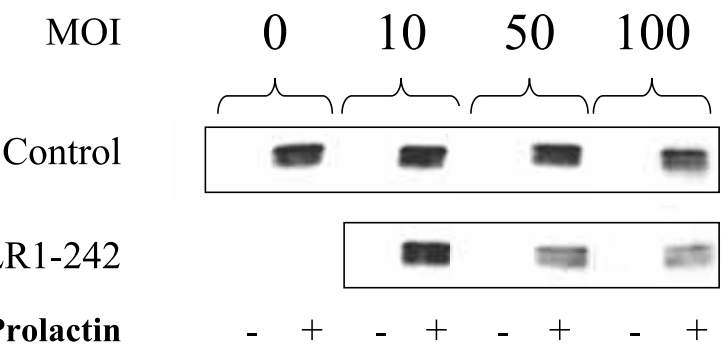

Figure 8 Inhibition of STAT5 activation by mutant prolactin receptor. T47-D cells transduced with different $\mathrm{MOI}$ of Ad0 or adenoviral vector expressing PRLR1-242. Cells were treated with $\mathrm{rhPRL}(250 \mathrm{ng} / \mathrm{ml})$ for 20 min before activated STAT5 was extracted using the STAT5 response element linked to agarose beads prior to Western blotting with anti-STAT5. 


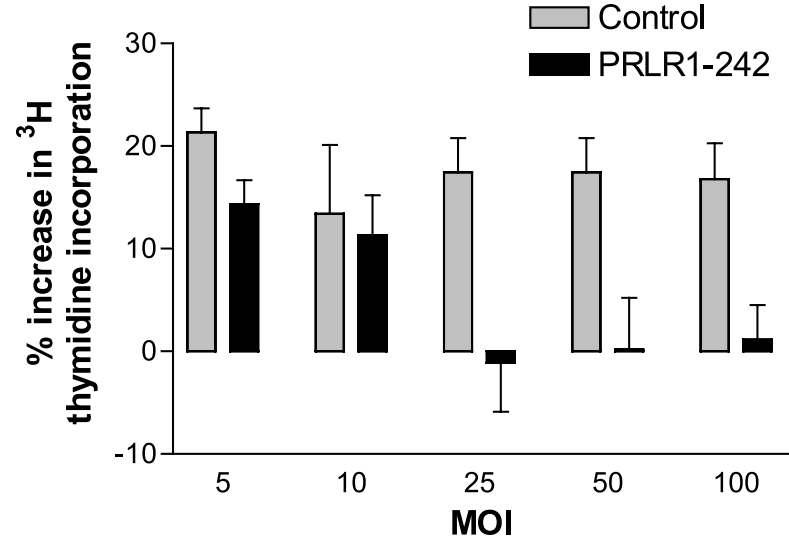

Figure 9 Inhibition of the proliferative response of T47-D cells by mutant prolactin receptor. Percentage increase in $\left[{ }^{3} \mathrm{H}\right]$ thymidine incorporation in response to prolactin $(500 \mathrm{ng} / \mathrm{ml})$ by cells infected with different $\mathrm{MOI}$ of Ad0 or adenoviral vector expressing PRLR1-242.

Error bars represent S.E.M. $(n=8)$.

virus expressing the PRLR1-242 mutant, however, there was a marked inhibition of STAT5 activation at an MOI of 50, and a greater inhibition at an MOI of 100 (activation reduced by $47 \cdot 7$ and $66 \cdot 3 \%$ respectively).

Finally, the ability of PRLR1-242 to block the mitogenic effect of prolactin on T47-D cells was tested. Initial studies revealed that the proliferative response of T47-D cells to prolactin is strongly density dependent, so that at least $2 \times 10^{4}$ cells $/ \mathrm{cm}^{2}$ were required to obtain a clear response. In all subsequent experiments, therefore, a density of $1.5 \times 10^{5}$ cells $/ \mathrm{cm}^{2}$ was used. As with STAT5 activation, an inhibitory effect of virus was manifested by a small decrease in thymidine incorporation when cells were infected with Ad0 (in the absence of virus, prolactin increased incorporation of thymidine by $28 \cdot 4 \%$, results not shown). When virus expressing the PRLR1-242 mutant was compared with Ad0, however, incorporation of thymidine was clearly inhibited at an MOI of 5, and at an MOI of 25 or greater the mitogenic effect of prolactin was completely blocked (Fig. 9). There was no difference in cellular response when virus expressing wild-type receptor was compared with Ad0 (results not shown).

\section{Discussion}

The importance of oestrogen in human breast cancer is well established, and anti-oestrogen therapy is in widespread use. It appears increasingly likely that prolactin, which exerts welldocumented effects on proliferation and migration of breast cancer cells, should be considered as an additional endocrine factor of importance in breast cancer (Goffin et al. 1999, Vonderhaar 1999, Clevenger et al. 2003). Particularly strong additional evidence for a role of prolactin is provided by a recent study showing a clear link between high serum prolactin and increased risk of breast cancer (Hankinson et al. 1999). The ineffectiveness of dopamine agonists can now be understood as resulting from autocrine/paracrine actions of prolactin in breast tissue, so there is an urgent need to find an alternative approach to targeting the prolactin receptor and preventing its ability to activate intracellular signalling pathways. To this end, prolactin antagonists are actively being sought. Although an antagonist that effectively blocks prolactin action has been described recently (Bernichtein et al. 2003), more work is required before long-acting and effective antagonism can be achieved in vivo. More importantly, dissection of prolactin effects also requires a means of targeting specific tissues. Our finding of a mutation in the human growth hormone receptor which causes short stature (Ayling et al. 1997) provided the basis for a novel approach to this requirement. The naturally occurring mutation that we identified results in severe truncation of the receptor cytoplasmic domain, and sequences required for activation of intracellular signalling pathways are lost. Internalisation motifs are also lost, providing a plausible explanation for the accumulation of mutant receptor at the cell surface which then forms inactive heterodimers with wild-type receptor. As a result of these characteristics, the mutant can effectively block signalling even at low levels of expression, so that this class of mutation exerts an unusually powerful dominant-negative effect. Here, we describe the characterisation of a corresponding mutation in the human prolactin receptor (PRLR1-242) that exerts a powerful dominant-negative effect on prolactin signalling.

Several variants of the prolactin receptor with truncated cytoplasmic domains have been shown to possess dominant-negative properties in vitro. In this respect, the naturally occurring rodent 'short' forms that are truncated at amino acid 291 have been most extensively investigated. A number of studies 
have shown that, lacking tyrosine residues required for STAT binding, these short forms exert a dominant-negative effect on activation of STAT5 by full-length receptor (Perrot-Applanat et al. 1997). Truncated variants identified in human tissues also exert a dominant-negative effect on STAT5 activation ( $\mathrm{Hu}$ et al. 2001, Trott et al. 2003). It is possible, therefore, that these naturally occurring short forms could play an important role in determining prolactin responses in target tissues. Although it is difficult to make a direct comparison of human PRLR1-242 dominant-negative activity with that of rodent short forms, PRLR1-242 appears markedly more potent than the naturally occurring short forms. When cells are transfected with equal amounts of plasmid encoding full-length and short forms, STAT5 activation by wild-type receptor is inhibited by about $50 \%$, and inhibition by $90 \%$ requires around a sixfold excess (Perrot-Applanat et al. 1997). By contrast, the PRLR1-242 mutant described in the present study effectively blocks STAT5 activation by the fulllength receptor even when plasmid encoding wild-type receptor is in excess. More importantly, the naturally occurring short forms retain box 1 , and so can bind and activate JAK2 (Lebrun et al. 1995). Thus they have the potential to activate signalling pathways, though whether or not they do so has been controversial, and may depend on a number of factors such as cell type and level of expression. Thus O’Neal \& Yu-Lee (1994) were able to rescue interleukin-3-dependent cell lines by transfection of full-length receptor, but were unable to do so with short form. In contrast, Das \& Vonderhaar (1995) found that the short form stably transfected in 3T3 cells was able to mediate activation of MAPK and proliferation in response to prolactin, thus raising the possibility that all truncated receptors retaining box 1 could activate other signalling pathways (Duan et al. 1996). Confirmation that this is indeed the case is provided by a recent study (Binart et al. 2003) showing that the short form is able to rescue mammopoiesis in heterozygous PRLR+/ - mice. In contrast, the more drastically truncated PRLR1-242 mutant which lacks box 1 clearly blocks the proliferative effects of prolactin in cultured breast cancer cells. Since the dominantnegative action of the corresponding growth hormone receptor mutant is active in vivo, it seems probable that PRLR1-242 will be similarly effective in vivo. Further studies will be required to confirm this prediction.

Several motifs involved in endocytosis of the prolactin receptor have been identified (Vincent et al. 1997, Lu et al. 2002), but all of these are missing from PRLR1-242. Deletion of these motifs has been shown to slow the rate of receptor internalisation, an effect that was also reported with a similar mutant form of the growth hormone receptor (Maamra et al. 1999). Thus, with time, differences in internalisation should lead to changes in relative expression of wild-type and mutant receptor that would contribute to the potent dominant-negative effect of the latter.

Using an adenoviral vector we were able to show that PRLR1-242 could effectively block the mitogenic effect of prolactin in human breast cancer cells. This approach will facilitate clarification of the precise role that prolactin plays in this disease, and could also provide a basis for targeted therapeutic intervention without compromising prolactin action in other tissues. Given the close similarity between both ligands and receptors, it is perhaps not surprising that PRLR1-242 also inhibits growth hormone signalling. Because growth hormone receptors are also expressed in breast cancer cells, this cross-reactivity could be an added advantage. The PRLR1-242 construct may also be useful in other situations. Thus, for example, there is evidence that prolactin (Leav et al. 1999) and growth hormone (Chopin et al. 2002) are similarly involved in human prostate cancer.

In conclusion, we describe a truncated mutant form of the human prolactin receptor lacking the box 1 motif that can be used to block signalling and proliferative responses to prolactin in breast cancer and other cell types.

\section{Acknowledgements}

Human GHRfl was kindly supplied by Dr Richard Ross. The $\psi 5$ adenovirus, pAdlox plasmid and CRE8 cell line were kindly provided by Dr S Hardy (Somatix, Alameda, CA, USA). Recombinant human growth hormone was a gift from Pharmacia.

\section{Funding}

This work was supported by the Wellcome Trust, the Cancer Research Campaign, and 
the Neuroendocrinology Charitable Trust. The authors have no conflict of interest that would prejudice impartiality.

\section{References}

Ayling R, Ross R, Towner P, Von Laue S, Finidori J, Moutoussamy S, Buchanan C, Clayton P \& Norman M 1997 A dominant-negative mutation of the growth hormone receptor causes familial short stature. Nature Genetics 16 13-14.

Beadling C, Ng J, Babbage JW \& Cantrell DA 1996 Interleukin-2 activation of STAT5 requires the convergent action of tyrosine kinases and a serine/threonine kinase pathway distinct from the Raf1/ERK2 MAP kinase pathway. EMBO fournal 15 1902-1913.

Bernichtein S, Kayser G, Dillner K, Moulin S, Kopchick JJ, Martial JA, Norstedt G, Isaksson O, Kelly PA \& Goffin V 2003 Development of pure prolactin receptor antagonists. Fournal of Biological Chemistry 278 35988-35999.

Binart N, Imbert-Bollore P, Baran N, Viglietta C \& Kelly PA 2003 A short form of the PRL receptor is able to rescue mammopoiesis in heterozygous PRL receptor mice. Molecular Endocrinology 17 1066-1074.

Bole-Feysot C, Goffin V, Edery M, Binart N \& Kelly PA 1998 Prolactin (PRL) and its receptor: actions, signal transduction pathways and phenotypes observed in PRL receptor knockout mice. Endocrine Revieres 19 225-268.

Chen TJ, Kuo CB, Tsai KF, Liu JW, Chen DY \& Walker AM 1998 Development of recombinant human prolactin receptor antagonists by molecular mimicry of the phosphorylated hormone. Endocrinology 139 609-616.

Chopin LK, Veveris-Lowe TL, Philipps AF \& Herington AC 2002 Co-expression of GH and GHR isoforms in prostate cancer cell lines. Growth Hormone and IGF Research 12 126-136.

Clevenger CV, Chang W-P, Ngo W, Pasha TM, Montone KT \& Tomaszewski JE 1995 Expression of prolactin and prolactin receptor in human breast carcinoma: Evidence for an autocrine/paracrine loop. American foumal of Pathology 146 695-705.

Clevenger CV, Furth PA, Hankinson SE \& Schuler LA 2003 The role of prolactin in mammary carcinoma. Endocrine Reviews $\mathbf{2 4}$ $1-27$.

Cunningham BC, Bass S, Fuh G \& Wells JA 1990 Zinc mediation of the binding of human growth hormone to the human prolactin receptor. Science 250 1709-1712.

Das R \& Vonderhaar BK 1995 Transduction of prolactin's (PRL) growth signal through both long and short forms of the PRL receptor. Molecular Endocrinology 9 1750-1759.

Duan WR, Linzer DI \& Gibori G 1996 Cloning and characterization of an ovarian-specific protein that associates with the short form of the prolactin receptor. Fourmal of Biological Chemistry 271 15602-15607.

Fuh G \& Wells JA 1995 Prolactin receptor antagonists that inhibit the growth of breast cancer cell lines. Fournal of Biological Chemistry 270 13133-13137.

Gebre-Medhin M, Kindblom LG, Wennbo H, Tornell J \& Meis-Kindblom JM 2001 Growth hormone receptor is expressed in human breast cancer. American Fournal of Pathology $\mathbf{1 5 8}$ $1217-1222$.

Ginsburg E \& Vonderhaar BK 1995 Prolactin synthesis and secretion by human breast cancer cells. Cancer Research $\mathbf{5 5}$ 2591-2595.

Goffin V, Kinet S, Ferrag F, Binart N, Martial JA \& Kelly PA 1996 Antagonistic properties of human prolactin analogs that show paradoxical agonistic activity in the $\mathrm{Nb2}$ bioassay. Fournal of Biological Chemistry 271 16573-16579.
Goffin V, Touraine P, Pichard C, Bernichtein S \& Kelly PA 1999 Should prolactin be reconsidered as a therapeutic target in human breast cancer? Molecular and Cellular Endocrinology 151 79-87.

Hankinson SE, Willett WC, Michaud DS, Manson JE, Colditz, GA, Longcope C, Rosner B \& Speizer FE 1999 Plasma prolactin levels and subsequent risk of breast cancer in postmenopausal women. Journal of the National Cancer Institute 91 629-634.

Hardy S, Kitamura M, Harris-Stansil T, Dai Y \& Phipps ML 1997 Construction of adenovirus vectors through Cre-lox recombination. Fournal of Virology 71 1842-1849.

Herman A, Bignon C, Daniel N, Grosclaude J, Gertler A \& Djiane J 2000 Functional heterodimerization of prolactin and growth hormone receptors by ovine placental lactogen. Fournal of Biological Chemistry 275 6295-6301.

Hu ZZ, Meng J \& Dufau ML 2001 Isolation and characterization of two novel forms of the human prolactin receptor generated by alternative splicing of a newly identified exon 11. Fournal of Biological Chemistry 276 41086-41094.

Kindblom J, Dillner K, Sahlin L, Robertson F, Ormandy C, Tornell J \& Wennbo H 2003 Prostate hyperplasia in a transgenic mouse with prostate-specific expression of prolactin. Endocrinology 144 2269-2278.

Leav I, Merk FB, Lee KF, Loda M, Mandoki M, McNeal JE \& Ho SM 1999 Prolactin receptor expression in the developing human prostate and in hyperplastic, dysplastic, and neoplastic lesions. American Fournal of Pathology 154 863-870.

Lebrun JJ, Ali S, Ullrich A \& Kelly PA 1995 Proline-rich sequence-mediated Jak2 association to the prolactin receptor is required but not sufficient for signal transduction. Fournal of Biological Chemistry 270 10664-10670.

Lochnan HA, Buteau H, Richards S, Edery M \& Kelly PA 1995 Functional activity of the human prolactin receptor and its ligands. Molecular and Cellular Endocrinology 114 91-99.

Lu JC, Scott P, Strous GJ \& Schuler LA 2002 Multiple internalization motifs differentially used by prolactin receptor isoforms mediate similar endocytic pathways. Molecular Endocrinology $162515-2527$.

Maamra M, Finidori J, Von Laue S, Simon S, Justice S, Webster J, Dower \& Ross R 1999 Studies with a growth hormone antagonist and dual-fluorescent confocal microscopy demonstrate that the full-length human growth hormone receptor, but not the truncated isoform, is very rapidly internalized independent of Jak2-Stat5 signaling. Fournal of Biological Chemistry 274 14791-14798.

Manni A, Boucher AE, Demers LM, Harvey HA, Lipton A, Simmonds MA \& Bartholomew M 1989 Endocrine effects of combined somatostatin analog and bromocriptine therapy in women with advanced breast cancer. Breast Cancer Research and Treatment 14 289-298.

Mertani HC, Garcia-Caballero T, Lambert A, Gerard F, Palayer G, Boutin JM, Vonderhaar BK, Waters MJ, Lobie PE \& Morel G 1998 Cellular expression of growth hormone and prolactin receptors in human breast disorders. International fournal of Cancer 79 202-211.

O'Neal KD \& Yu-Lee LY 1994 Differential signal transduction of the short, Nb2, and long prolactin receptors. Activation of interferon regulatory factor-1 and cell proliferation. Fournal of Biological Chemistry 269 26076-26082.

Paris N, Rentier-Delrue F, Defontaine A, Goffin V, Lebrun JJ, Mercier L \& Martial JA 1990 Bacterial production and purification of recombinant human prolactin. Biotechnology and Applied Biochemistry 12 436-449.

Perrot-Applanat M, Gualillo O, Pezet A, Vincent V, Edery M \& Kelly PA 1997 Dominant negative and cooperative effects of mutant forms of prolactin receptor. Molecular Endocrinology 11 1020-1032. 
Ross RJ, Esposito N, Shen XY, Von Laue S, Chew SL, Dobson PR, Postel-Vinay MC \& Finidori J 1997 A short isoform of the human growth hormone receptor functions as a dominant negative inhibitor of the full-length receptor and generates large amounts of binding protein. Molecular Endocrinology 11 265-273.

Tanaka T, Shiu RC \& Gout PW 1980 A new sensitive and specific bioassay for lactogenic hormones: measurement of prolactin and growth hormone in human serum. Fournal of Clinical Endocrinology and Metabolism 51 1058-1063.

Trott JF, Hovey RC, Koduri S \& Vonderhaar BK 2003 Alternative splicing to exon 11 of human prolactin receptor gene results in multiple isoforms including a secreted prolactin-binding protein. Fournal of Molecular Endocrinology 30 31-47.
Vincent V, Goffin V, Rozakis-Adcock M, Mornon JP \& Kelly PA 1997 Identification of cytoplasmic motifs required for shortprolactin receptor internalization. Fournal of Biological Chemistry $2727062-7068$.

Vonderhaar BK 1999 Prolactin involvement in breast cancer. Endocrine-Related Cancer 6 389-404.

Welsch C \& Nagasawa H 1977 Prolactin and murine mammary tumorigenesis: a review. Cancer Research 37 951-963.

Received in final form 26 November 2003 Accepted 3 December 2003 